The National Library supplies copies of this article under licence from the Copyright Agency Limited (CAL). Further reproductions of this article can only be made under licence.

\title{
Good Girls Don't: Gender Ideologies in Touching Earth Lightly and Wolf
}

\author{
Joanna Harris
}

$\mathrm{T}$ The novels Touching Earth Lightly, by Margo Lanagan, and Wolf, by Gillian Cross, deal with the ways in which children are allowed and encouraged to progress through the developmental stage of adolescence (a period delineated differently by these two writers) towards adulthood and the acceptance of the responsibilities and behaviour required by adult society The narratives demonstrate that in the contemporary cultures depicted in these two particular novels there is no clear boundary to cross, no rite of passage in either the British or Australian tradition of becoming an adult, and that consequently the positions of the young female protagonists are often ambiguous. Sexual maturation is not regarded as the attainment of adequate preparation for parenthood; emotional maturity is given far greater weight. Similarly, the right to vote does not necessarily imply political acuity, so that coming of age has diminished as a significant marker. These ambiguities are reflected in the narratives in diverse ways: in discussions of questions of morality, in the manner in which the dilemmas and intemal struggles of the central characters are revealed to the reader, in characters' attempts to resolve the issues presented by an adult world, and in literary devices such as intertextuality and forms of closure. The texts can be shown to construct ideological perspectives expressed within the narratives by the endorsement of modes of action designed to facilitate survival and success. The imaginary dangers of childhood fantasy, the monsters, ogres, witches, and dragons so easily conquered in the realms of enchantment are transformed into life-threatening actualities, and the possibilities of grievous damage given terrifying form. How this 'realism' is confronted and resolved is indicated in the extent to which the characters Chloe and Cassy are permitted to become 'adult', both in the degree of licence given to them to act independently and in the scope which they are given to develop as selfreliant, confident individuals with the inner strengths and abilities necessary to find their own place in the world. That a place exists for them is again an ideological parameter implicit in both the texts. Although the differences between inscriptions of ideology in Wolf and Touching Earth Lightly may be due in part to the difference in age between the two girl protagonists (and the implied readers of the texts), there are other factors at play.
One of the most significant ways used to define the boundary between childhood and adulthood lies in the forms of interaction and communication between the two groups. Adolescence is often perceived by adults, particularly parents, as a dangerous period for children. In an article entitled 'Failing a generation: youth and the crisis in westem culture', Richard Eckersley cites surveys of public opinion and attitudes of contemporary Australian society, which indicates a growing cultural despondency, showing
a people who, beneath a professed personal optimism, nonchalance and hedonism, are fearful. pessimistic, bewildered, cynical and insecure: a people who feel destabilised and powerless in the face of accelerating cultural, economic and technological change; a people deeply alienated from the country's major institutions, especially government.
(Eckersley 1994, p.33)

And this malaise, Eckersley says, is reflected in an increasing concern for the welfare and future of children.

Writing for young adults, particularly fiction, is perceived as a forum through which readers can be exposed to the issues which influence and shape society, but as there is no prevailing consensus on the appropriate age or stage at which adolescents should be exposed to information, there is continuing controversy about the idea of boundaries between adolescent and adult knowledge. Two of the most prominent matters which provoke debate on what should or should not be censored are sexuality and death, with particular attention paid to the extent to which focalised characters engage directly in actions that transgress certain social mores. Touching Earth Lightly explores many of these hot issues: incest, teenage pregnancy, self-abuse, brutal murder and violence are all described quite graphically. Margo Lanagan justifies the inclusion of such material:

This is reality literature; it makes ghouls of us the way reality lelevision does; it 's close to the bone. It makes us look at things which, as adults, we 've become used to avoiding. We have constructed adult lives for ourselves where we socialise only 
with people whose company we enjoy. walk through only pleasant environments, and think only about issues we feel we can be useful in. We like to think positive and to feel safe, and that's what we want our children to do, too.

In the process of making the world over to suit ourselves, or rather of retiring to a small corner of $i$ and erecting screens all around ourselves. we have made over our own memories.

$(1997$, p. 19)

Lanagan here expresses an ideological viewpoint about where she believes a line should be drawn between adult and adolescent knowledge and experience, but it is interesting to note that the most confronting episodes in Touching Earth Lightly involve emotionally and culturally deprived, poorly-educated Janey while Chloe, the daughter of nurturing, liberated, enlightened, university-educated parents, is able to grow and learn from the devastating death of her friend.

The liberal, friendly atmosphere of the Hunter household, where affection between parents and children is openly expressed, where Janey is welcome and has found shelter and support during her pregnancy and in the process of relinquishing her baby, is reprèsented as idyllic. After accompanying Janey on her search for a cheap room in a shabby boarding house, Chloe comes back to a 'warm house, into the smell of wood fire and roasting lamb' (Touching Earth Lightly, p. 21). Communication is highlighted: the banter between the members of the family and their friends is light-hearted but caring, and the custom of holding open house on Sundays fosters serious discussion of a philosophical and intellectual nature which is considerate and inclusive of the views of the younger generation. When Isaac expounds his passionate ideas about the effect of bad architecture on self-esteem he is taken seriously in this milieu and provokes a lively debate:

'You live in that kind of space, you end up thinking that's the only kind of space you deserve. And it's bad for the people outside, too. When these things stop being eyesores and start being invisible because they're so familiar, I think everyone should start to worry about what's happening to us inside, to our eyes, to our minds...'

(p.35)

This perception reinforces Chloe and Janey's earlier discussion aboul whether Janey deserves even the threadbare comforts of her rented room and highlights her doubt in her ability to maintain an existence apart from destructive influences:

Janey took her new bedside lamp out of its box and admired it, and read aloud its guaraniee ticket. 'This is a bit flash, isn't it?'

'For a girl from the back streets, you mean?' They looked at each other. It was exactly what Janey meant. She sparkled at Chloe, then looked anguished. 'Ooh, if I can only...'

$$
\text { (p.21) }
$$

But Janey is drawn to people who exploit and damage her, like Bass, and Chloe is then rejected - 'the shutters go down in Janey's eyes' ( $p .42$ ). Janey is nonetheless shown to be articulate and aware of her own shortcomings, and of the differences between her own and Chloe's expectations for themselves. She places her own wishes for a secure future, for a baby she could keep and for stability - 'a life, you know, an occupation, some kind of thing that goes on' (p.24) - in the realm of fantasy, contrasting it with her certainty that Chloe will achieve her dreams. The narrative juxtaposes images of Chloe's 'civilised brothers' with Janey's 'dirty old man' (p.38), and the way the word 'mother' is used as a term of abuse is contrasted with Chloe's 'brilliant mother' ( $p .52$ ). Janey's doubts are mirrored by a growing realisation in Chloe that there are limits to the extent to which she can continue to intervene in Janey's life. Janey's attraction for Chloe stemmed from the desire 'to be rescued from her own timidity, her own steadiness' and the excitement generated by Janey's subversive behaviour. She admires Janey's ability to be dominant in her sexual adventuring, to 'call the shots' (13), but worries about her lack of discrimination. (43) To Chloe, it seems that in order to become adult, she must give up her role as protector, even though it may mean seeing less of Janey, and model herself on her parents, who she has lately discovered have pursued a conscious policy of allowing Chloe and her 
brothers to make their own decisions, even 'sometimes in the face of their own doubts' (37).-Janey herself realises that she cannot go on being rescued by the Hunters:

'Every time it's the same. like you say. I get a photo and everything falls apart, and you guys put it all back logether again for me. I can't work out a way of doing that for myself. Why can't I?' 'Maybe there isn't a way, yet.'

'But what if there isn'tever? 'Chloe felt fright run down Janey's back. 'What if I can never? And Cole minding me when I go off the deep endwhat, is she going to do that for the rest of her life?' Her voice went deep with holding back sobs, 'I don't think so.'

Chloe felt excluded, talked about as if she wasn't there. This was some kind of knot between her mother and Janey; something bigger and more complicated than the simple promise Chloe had made, back when the pattern of Janey's hormones was first making itself obvious. Had it been silly, childish, to offer her help? Was it something she and Janey ought to grow out of? Ought Janey be trying to cast her off? This seemed to be what, or part of what, Janey and Joy were wrestling about. Chloe stood to one side, wondering who made all these rules, and how Janey and Joy knew about them

(p.66)

Joy.'s acceptance and love of Janey, her understanding of Janey's continually resurfacing grief at the loss of her child and her reassuring conviction that things will work out, simultaneously comfort Chloe and make her despair that she can ever be as strong as her mother, 'a fine, finished person' (p.67). On the other hand, Chloe sees herself as 'failing everyone, to some degree' (ibid). Joy is even able to successfully confront and rebut Nathan, Janey's brutish brother, who threatens and frightens Chloe (p.48). This dilemma precipitates Chloe's actions on the day of Janey's murder. The narrative foregrounds Chloe's sense of inadequacy by contrasting Janey with the normality of Nick, Isaac and Rachel. Chloe feels that her loyalty to Janey is questioned, 'as if one of her arms had fallen off, leaving a cold, unbalancing space' (p.78), and, while afraid that Janey might succeed in seducing
Nick, is muddled by anger at him for not wanting Janey. Part of Chloe wants Nick to take on the burden or responsibility for Janey, to take the weight from her, but she also does not want to lose Janey's companionship. Throughout the narrative, Chloe's brother Nick and his friend Isaac have acted at times as guides. They appear to have successfully made that next step forward out of adolescence towards adulthood; these young men seem to Chloe to be definite in their opinions and secure in their choice of career:

They were so confident now about stepping forward and claiming their adulthood - how did they do that? Chloe felt herself caught in an endless hesitation, herself, with possible lives multiplying all around her, none of them notably more attractive than the others. Life was going past while she stood still, watched and wondered and looked for a good place to jump on. What if she didn't find one? What if there wasn't one, for her?

$$
\text { (p:40) }
$$

Nick makes it clear that he sees Janey as someone who will take over his life - as he infers she dominates Chloe's - if he allows her to become attached to him. Chloe's role as the Ice Princess is work that gives her adult status, bringing her closer to the desirable adult world. The structure of work and commitment, combined with her feeling of being unable to deal with the enormity of Janey's problems causes Chloe to try and push Janey into seeking professional help, despite Janey's protestations that she 'hates seeing that my whole life disgusts people, that it's a big dirty hole that I'm always having to be dragged out of' ( $p .82$ ). The theatrical image of the frozen character is first used to express Chloe's anger at 'being on the run after Janey; she just wanted to sit still, to feel nothing' (p.95) and then frustration, when she realises where Janey must be, at being unable to discard this role. After the discovery of Janey's body, in the process of mourning her loss, the symbolism of the Ice Princess conflates with the helplessness and stillness occasioned by her guilt at choosing frivolity before her friend's needs. What had seemed like an adult choice had been the wrong choice. 
Chloe's acceptance that she failed Janey, her resolution to accept some responsibility for Janey's death and being in some measure remiss in not acting more resolutely to help Janey change her own life. is depicted as adult behaviour. Joy's declaration that she shares Chloe's belief that she is culpable, and her conviction that she has left Chloe to bear too much of the burden of Janey's difficulties, is mitigated by Dane's comments that Janey's death was bad luck (p. 182). An adult view of the situation is presented as a complex view, not a balanced perspective, but a 'realistically' unresolved and unresolvable way of seeing. This is undermined, however, by the manner in which the narrative embeds within the text the ideology that Janey's death was fated. The sense that Chloe and her family are implicated in responsibility for Janey's death is too weak to subvert the major ideological premise of the text - that is, that Janey is destined to die, both because of her abusive family situation and because her resulting lack of self-worth precipitates her into acts of selfdestruction. Her position in the social strata is clearly described. Lanagan has linked the financial situation of Janey's family with dirtiness, neglect, and uncaring parental attitudes which have pushed Janey out into a dangerous world, where she is unprepared for the task of dealing with the consequences of risky behaviour and vulnerable to the predatory actions of others. Acts of violence are depicted as commonplace occurrences between people of Janey's class, in contrast with the articulateness and rationality of Chloe's middle-class background. Chloe is shown to be protected by her class from the brutality to which Janey is automatically exposed. Chloe has the privilege of being able to choose to be more or less supportive, but Janey is given few choices and those are very limited and constrained by overwhelmingly oppressive circumstances.

Chloe thinks in a daze. feeling baby-like and babied, wrapped in this house and family whose pain can't ease hers by even the smallest degree. because she isn't armed against a night like this. Police, morgue, injuries - she's gone along in all innocence, never dreaming these words might be used of Janey, but now that she looks back of course they were coming - she should have seen them flapping like vultures over Janey all along. from way back in the schoolyard, and in a tall column spiralling up on the thermals of evil grotty heat from Janey's house. All Janey's life people had beendrawing back from her, baulking, looking askance, doubting, being 'concerned'. consulting each other - for this reason, that they are grown up and know, have seen, that these things can happen, in this world, now, to real people. They've seen the vultures, and theydidn't tell her. Or they did, sort of, by all that fuss and worry, but they never actually made her listen. made her understand, made her know too. (p.113)

The narrative operates as a kind of Struwwelpeter for nicely bought up young girls, a warning that they should not put themselves in danger. Despite Janey's artistic brilliance and joie de vivre, she has not been able to escape her destiny. Peter Hollindale, in the article 'Ideology and the children's book', contends that ideology is

an inevitable, untameable and largely uncontrollable factor in the transaction between books and children, and that is so because of the multiplicity and diversity of both 'book' and 'child' and of the social world in which each of these seductive abstractions takes a plenitude of individual forms. Our priority in the world of children's books should not be to promote ideology but to understand it, and find ways of helping others understand it, including the children themselves.

(1988, p. 10)

Lanagan, rather than extending an understanding of the social forces which shaped Janey's existence, has promoted a misleadingly simple perspective to explain the circumstances of Janey's murder. As focalised through Chloe, Janey's death is described as an arbitrary accident, 'a matter of timing and slips in someone's concentration' (Janey's? the juveniles'? God's?), 'and the wrong constellation of power and fluids' (p. 164), insights that are disempowering rather than enabling. To offer any explicit judgment, other than the nebulous comforting words that Chloe's parents should have done something 
more, would perhaps be seen as too concrete for adolescents to deal with or perhaps too political. Although Lanagan decries the 'astonishing practice of whiting out swear-words and sex scenes in books on school library shelves' ( $p .88$ ), pushing the boundaries in Touching Earth Lightly by promoting discussion of sexual morality and normalising homosexuality through her representation of Carl and Gus, and their friendship with the Hunter family, she nevertheless creates an implicitly classist narrative which favours a happy ending only for the fortunate Chloe. The novel's impression of realism is muted by the conformity of the scenes of closure, a romanticism bereft even of any sexual innuendo, a conclusion that is consistent with the authorial killing-off of Janey. Kristeva identifies the abject - represented by Janey in this text- as:

the underside of the symbolic. It is what the symbolic must reject, cover over and contain. The symbolic requires that aborder separate or protect the subject from this abyss which beckons and haunts it: the abject entices and attracts the subject ever closer to its edge. It is an insistence on the subject's necessary relation to death, to animality, and to materiality, being the subject's recognition and refusal of its corporeality. The abject demonstrates the impossibility of clearcut borders, lines of demarcation, divisions between the clean and unclean, the proper and the improper..

(Grosz in Fletcher and Benjamin 1990, p.89)

Margo Lanagan has striven to place the abject within firm boundaries so that young readers' curiosity about the monsters bred in the world is satisfied and their seductive power reduced by being placed safely and gently 'between the pages of a book' (Lanagan, p.24).

The use of realism in Touching Earth Lightly is a powerful tool in conveying an ideological message because it carries the implication of 'truth'. John Stephens discusses the claims of 'realist' writing in children's fiction as follows:

... it is claimed that realism typically illuminates

life as $u$ is, presenting social and personal concerns in a context which includes a range of human desires and responses; it reflects society, and in doing so by means of a fictional construct, or representation, can offer its audience new experiences and help children mature intellectually and emotionally by enabling them to experiment with subject positions by engaging with them at one remove from consensus reality. (1992, p.242)

From how 'realism' is shaped to serve the ideologies of Touching Earth Lightly it can be deduced that the 'truth' which it is intended to demonstrate is equally elusive.

Gillian Cross's Wolf is an overtly realistic narrative, cleverly underpinned and interwoven with intertextual references which are used to set up readers' expectations and then subversively confront them. The plot follows Cassy's discovery that her father is an IRA bomber intent on retrieving plastic explosive even if this means harming his own family, but the implications of the text are concemed with an exploration of what is 'real'. The novel thus attempts to disclose the operations of ideology within sociality.

Adolescence, as focalised through Cassy, is depicted as a search for identity. Cassy behaves like an imprinted duckling who has unquestioningly assumed the values and attitudes of her grandmother. The pervasive societal view that the safest, most nurturing cultural structures for promoting good child development are the "reliable and unchanging' values (p.27) expounded by Nan are undermined by the twist they are given. Maxims spoken by her grandmother and repeated by Cassy to comfort and reassure herself are framed by the narratorial voice in a manner which mocks their homespun wisdom:

She lay down again and closed her eyes, wiping her mind clean and willing the questions away. Mind your own business, Nan always said, and you won't get your nose caught in my mousetrap. No questions. No thinking at all. The blankness came easily from long practice, and she floated into a dreamless sleep.

(p.3) 
Unquestioning obedience is here given an imputation of brainwashing, of mindless conformity.

When she tries to fit the pattern of her rigid, narrow existence onto the seemingly chaotic world of her mother and life in the squat, she is challenged by Lyall and his son Robert. The obsessive cleaning and ordering which is Nan's trademark, her repression of imaginative thought and her disapproval of the worth of pleasure and fun are questioned, especially by Robert, whom Cassy has come to trust. In some degree, like Nick and Isaac in Touching Earth Lightly, Robert acts as a mentor, forcing Cassy to look beyond the artifice of Nan's meaningless platitudes, and bromides like 'Never trouble trouble until trouble troubles you' (p.48), which are used to stop Cassie's questioning of the 'normal' life Nan has established. Cassie's unquestioning compliance is necessary for the continuing provision of a bolthole for her renegade son. When Goldie and Lyall return from a performance exhilarated and jubilant, Robert confronts Cassy's disapproval of their enjoyment of work, pushing her to provide her own reasons for her attitude, to acknowledge her own feelings and desires instead of mouthing Nan's words. (p. 60-1) But it is obvious that Nan has imbued Cassy with a fear of unleashing a nameless horror if she allows herself to speculate on anything. Her reluctance to use her imagination is made clear as they rehearse the play of The Three Little Pigs:

Lyall grabbed her by the shoulders. 'Forheaven's sake, girl! Imagine! You might be surprised by what you come up with. Let your mind Go.'

Never, never. Cassy's mind closed tight, like a fist clenching, and she glared at Lyall.

(p. 88)

Cassy, however, can only act the comfortable role of Nan. The way in which she makes the "walls of her imaginary house straight and exact, and the comers perfectly square' (ibid), illustrates the rigid emptiness of Nan's doctrines and emphasises Cassy's terror.

The wolf is the symbol of the foreboding dread which threatens to destroy Cassy's carefully manufactured impression of her proper and safe life with her grandmother Cross's deconstruction of the meaning and resonance of the word 'wolf' parallels Cassy's unpicking of her own reality. The narrative is infused with intertextual references, the principal one used being Red Riding Hood. The analogy with the character of Red Riding Hood is initially evident from the reference to her hood, which, 'like blinkers, shut out the view on either side' (p.11), as she travels across London looking for her mother, whom she discovers, alarmingly, in the wood with the wolflike Lyall:

It was like walking into an infinite forest, full of fireflies...

The room had no limits. Left and right, behind and in front and above, the lights and the flowers surrounded her with patterns that destroyed her sense of space. The shock of it froze her brain and she gripped the handle of her suitcase, standing completely still as she worked out where the boundaries were.

It took her more than a minute. Slowly she realized that she was looking at reflections. The only real lights were two candles, standing in bottles in the middle of the floor. Their flames were reflected backwards and forwards, over and over, up and down, in a hundred fragments of mirror. (p.14)

The Red Riding Hood story is here extended through its introduction into a fantastic world, an illusory labyrinth of mirrors. Moving from the known world of childhood is compared to stepping into a maze or, like Alice falling down the rabbit hole, into a place where nothing is quite as it appears. Like a hero of the romantic mythos, Cassy is forced to leave the secure environment where she is 'at equilibrium with society' (Hume 1984, p.152), and enters a precarious and contentious environment defiant of the constraints of the property owners. The notice on the door of the squat defying authority with its 'lively border of flames and weapons and monsters' (p.12), is reminiscent of thresholds crossed into fantastic worlds 'characterized by magic or other non-rational, non-normal forces.. [where] the hero undergoes tests and trial, survives adventures, and finally emerges triumphant' (Hume, p.152). This narrative undercuts some of the traditional conventions of the folktale, producing an ironic mythos, 
a process which 'violates... expected logic' (Hume, p. 155), and, in an inversion of the ending, effects a denouement which reverses Cassy's perception of Goldie. As Adrienne Kertzer notes in 'Reclaiming her maternal pre-text', the roles in Wolf are continually shifting, undermining stereotyping and confounding expectations. The protagonist is setting out to meet her mother and is sent by a grandmother who has established preconceptions which discredit the voice of the mother, aligning her with the unsubstantial, illusory qualities of fairytales, supported within the text by her name and her appearance, which link her with the childish heroine Goldilocks (Kertzer 1996, pp.21-3). Cassy imagines Goldie's character to be 'blithe and innocent' until the climax, when Goldie assumes the protective role of a maternal wolf. Indications of a more adult persona are disclosed to the reader Goldie's own denial of stupidity, her attempts at affectionate behaviour, her skill at acting - but they are minimised in Cassy's mind by the force of her grandmother's indoctrination. Robert's revelation that Goldie had not wanted to relinquish her daughter to Nan's care (p.57) and his later judgement of Nan's treatment of Goldie prompt Cassy to rethink the version of events she has always accepted as correct. It is an uncomfortable proceeding:

The thought slid into her mind and lodged there. like a sliver of ice. She had never thought of it like that before - but she realized, now, that she had always known. All these visits to Goldie were nothing to do with keeping in touch with her mother. They weren't for Cassy's benefit at all. Nan sent her to Goldie's to get her out of the way of something.

$$
\text { (p.71) }
$$

Cassy's realization that she has been exploited by Nan to provide a camouflage for Mick Phelan's activities is illuminating but confusing for her, since she finds it difficult to accept that she is not unconditionally loved and wanted by her grandmother in her own right. The protective instinct demonstrated by Nan's behaviour in sheltering her son is aroused in Cassy as she acts to cover up for her mother, and by extension for her father, shielding her from Lyall's intrusive questioning (p.73).
Cassy is learning that people and their motives are complicated, and that what she has assumed to be 'real life' is insubstantial and ephemeral:

'What is this thing you've got about real life?' Robert said quietly. 'Real life and real people? That doesn't mean anything. It's just a way of making walls, to shut out what's uncomfortable. And it doesn't work, you know. If things are there, you have to admit it in the end. '

Cassy caught her breath. That was too close. As though he had seen into her mind.

(pp.81-2)

The uncomfortable facts she has to confront are the knowledge that her father is wanted for killing innocent bystanders for the political cause espoused by the IRA and that what she had thought was plasticine is plastic explosive, harmless in itself but potentially lethal.

Interwoven with the progressive development of Cassy's insights into her situation are descriptions of the building of the performance piece Wolf. The papier maché masks are assembled from scraps of newsprint, which at first, 'criss-crossing at random, confused Cassy's eye and disguised the shapes' (p.29). Lyall's comment that she needs to understand before she can join them in constructing the masks can be viewed as a metaphor for Cassy becoming part of the household, and, by extension, the wider world. As the narrative continues, this message is further emphasised as she is needed to act in the play and it is made clear to her that Nan's way of treating her as a child whose needs are met by others is that of a person who does not accept a proper part in society. Again, it is Robert who challenges Cassy when she claims that she should be exempted: "'Why not?... You're living here, aren't you? Eating our food? Why not help to earn the money?"' (p.81) Adolescence is depicted as an emergence from a child's world where everything is provided, from opinions and beliefs to the practical necessities, into an adult world in which Cassy is expected to be an active, thinking participant with responsibilities to the other members of society. It closely resembles the model theorised by Erikson:

Adolescent development comprises a new set of 
identification processes, both with significant persons and with ideological forces, which give importance to individual life by relating it to a living community and to ongoing history, and by counterpointing the newly won individual with some communal solidarity.

(Erikson 1965, p.23)

Erikson identifies fairytales and folklore as one of the main influences of the continuing cultural transmission of moral and evil prototypes. The image of the wolf traditionally conjures up a spectre of malevolence. The use of a mask which has a 'realistically' terrifying appearance, is nevertheless convincingly scary when worn by Lyall because it carries the associations with her father which haunt her unconscious, resurfacing unbidden in her dreams and becoming a tangible fact of her existence:

'Lyall-'

He turned.

For a split second, her brain froze, putting everything into slow motion. Repeating the same image, over and over again.

He turned - and instead of his foce, there was a senseless, nightmare shape.

...The wolf where no wolf should be. Behind the door, invading the house, inside the skin of a familiar, trusted person-

Werewolf. Bzou. Loup garou, ligahoo, lagahoonightmare babble for a nightmare from the dark corners of the mind.

(p.110)

In the same way that the play opposes the fantasy wolf of imagination and story to scientific fact and the video of the captive wolves at the zoo, the 'Big Bad Wolf' persona assumed by Mick Phelan is challenged by Cassy as a false representation. During her performance in the drama she relates the image of her father to the image of the wolf 'he was there in her mind, matched against each new fact' (p.124). When she finally resolves on acting alone, it is in the context of theatre, 'a wild dramatic gesture', but it is with the realisation that the safe, sensible' philosophy espoused by her grandmother is useless, for she has discovered that happy endings are inevitable only in story: 'No woodcutter was going 10 leap in...' (p.130).
Cassy assumes the role of the hero, and in her newfound assumption of adult responsibility gained from confronting her nightmares and learning to trust her own judgement of the requirements of the situation, contests her father's presumption in likening himself to a wolf, comparing the imagery of the nurturing behaviour of the zoo animals to Phelan's betrayal of his mother and child:

'What's so important, then? What's big enough to make you tie up your own mother and shoot your child? Come on, Mick the Wolf. Tell me about it.'

(p.137)

Cassy here speaks to her father as an equal, on his own ground, contesting his actions and beliefs critically and rationally.

Unlike Chloe, who has been allowed to develop only along a predetermined path, Cassy's transition from adolescence to adulthood in $W$ olf has been an experiential broadening of possibilities. The world in both texts is represented as dangerous and uncertain, but while Lanagan reinforces conformity to the established patriarchal order as the most appropriate mode of becoming a woman, Cross presents positive affirmation that it is permissible and necessary to be assertive and self-determining. Her feminist reworking of Red Riding Hood does not explore the sexual innuendoes which Jack Zipes claims have been sanitised in both the Perrault and Grimm versions to produce sexist narratives whose illustrations endorse 'male power and rationalise male domination as the norm (1986, p.233); however, the inventiveness and evasive action Zipes describes as characteristic of the protagonist in earlier forms of the folktale, which allow Red Riding Hood to escape by using her own initiative (pp.228-90), is revived in this modern adaptation, with the additional element that the plot gives the maternal figure heroic status, further suggesting that to transgress from the prescribed order will not inevitably result in disaster. Erikson stresses that part of the process of growth and becoming is a generational challenge:

To enter history, each generation of youth must find an identity consonant with an ideological promise in the perceptible historical process. But 
in youth the tables of childhood dependence begin slowly to turn: nolonger is it merely for the old to teach the young the meaning of life, whether individual or collective. It is the youth who, by their responses and actions, tell the old whether life as represented by the old and as presented to the young who carry in then the power to confirm those who confirm them and, joining the issues, to renew and to regenerate, or to reform and to rebel.

(p.24)

The closure of Wolf affirms that life is continuing but unpredictable. Cassy's discussion with Robert, set, significantly, before the soon-to-be-phased-out wolf enclosure. explores Cassy's awareness that there is no simple resolution, only persisting difficulties. The implication in Robert's assurance that Nan and Goldie are still the same people, and that it is only Cassy's perception of them that has changed, is that she is now more able to cope with life's problems as they arise. His quip "'You need to plan the rest of your life now?"' ( $p$. 139 ) is answered with corresponding ironic humour by Cassy: "And all we have to do is live happily ever after?"' (p.140) Through such an empowerment of the hero, Cross succeeds in suggesting to the reader that it is possible, despite the restrictions of an adult world, to deal with adverse and threatening situations and to move from childhood through adolescence to adulthood and to challenge the status quo. Transgression within the narrative structure has reinforced subversive ideology, and it has been realised by exposing 'the spaces within the sign' (Stephens, p.247), producing figurative effects through 'dislocations of surface meaning, violations of the audience's sense of empirical reality' (p.246). For as the multiple meanings attributed to the wolf demonstrate, " the relationship between signifier and signified is arbitrary and unstable, and is the primary site on which semantic shift takes place' (ibid).

Cross's deconstruction of the wolf reveals the multiple meanings and resonances that can be attached to signs that may appear on first viewing to be capable of representation in only one way. In demonstrating how language can be manipulated 10 convey the intent of the writer, the text opens up to the reader the idea that ideology can be embedded within discourse in ways that may seem to be 'real' but may not necessarily be completely true. What Cassy does not know about her father, the omissions from her knowledge, are shown to be just as significant as the limited information allowed to her by her grandmother. The narrative acts to empower young adults by uncovering the cultural and historical influences that may infuse a text with significance and influence readers to unknowingly accept a particular ideology. The moral of this version of Red Riding Hood is that it is wise to question all information, to push the boundaries, in contrast to the advice implied in Touching Eorth Lightly.

These two works of fiction, written as they are for adolescent readers by adults, clearly have a specific didactic purpose beyond their function as entertainment. The ideology of the writer, whether implicitly or explicitly communicated by the narrative, shapes the form and scope of information and cultural precepts to be made available to the younger generation. Touching Earth Lightly has a covert agenda which reinforces conservative mores. Classism and sexism pervade the cultural messages of a determinist philosophy which exploits a quest motif but restricts success to a narrow range of appropriate behaviours. Wolf, on the other hand, which bypasses graphic descriptions of sexual deviance and mindless violence, is able to conjure up menacing imagery with intertextual references. By involving the young adult protagonist in the process of deconstructing the influences which have generated her perception of reality and in allowing her to become an agent within it, the text condones a widening of attitudes. In Wolf, the boundary to the adult world is presented as a state of mind, and rather than reinforcing a set philosophical position as Lanagan attempts to do in Touching Earth Lightly, Cross is concerned to provide young adults with the skills to understand the workings of ideologies and thus the ability to assess the paradigms offered to them upon critical consideration of their merits. The visions of adult society advanced by these two writers oppose one another absolutely. Lanagan's text supports conformity by disempowering the protagonists: Janey is killed, Chloe is to be married off. In contrast, Cross valorises Cassy's 
courage in challenging the boundaries imposed on her by affirming her growth in confidence and her increased autonomy.

\section{REFERENCES}

Christian-Smith, Linda (1990) Becoming a Woman Through Romance. London and New York, Routledge.

Cross, Gillian (1990) Wolf. Oxford, Oxford University Press.

Erikson, Erik H. (ed)(1965) The Challenge of Youth. New York, Anchor Books.

Fletcher, John and Benjamin, Andrew (eds) (1990) Abjection, Melancholia and Love: The Work of Julia Kristeva. London, Routledge.

Hollindale, Peter (1988) 'Ideology and the children's book', Signal 55, 3-22.

Hume, Kathryn (1984) Fantasy and Mimesis: Responses to Reality in Western Literature. New York and London, Methuen.

Kertzer, Adrienne (1996) 'Reclaiming her maternal pretext: Little Red Riding Hood's mother and three young adult novels', Children's Literature Association Quarterly 21, 1, 20-27.

Lanagan, Margo (1996) Touching Earth Lightly. St Leonards, Allen \& Unwin.

Lanagan, Margo (1997) 'The hand that wields the liquid paper: Censorship and young adult fiction', Metaphor $4,17-26$.

Nieuwenhuizen, Agnes (ed.) (1994) The Written World Youth and Literature. Port Melbourne, D W Thorpe.

Stephens, John (1992) Language and ldeology in Children's Fiction. London, Longman.

Zipes, Jack (1986) Don't Bet on the Prince: Contemporary Feminist Fairy Tales in North America and England. London, Gower.

\section{BIOGRAPHICAL NOTE}

Joanna Harris has worked in bookshops, studied photography and helped to run a photographic gallery. She completed a B.A. majoring in Literary and Australian Studies at Deakin University in 1996 and will complete an M.A. in Literary Studies in 1999, all by off-campus study.
